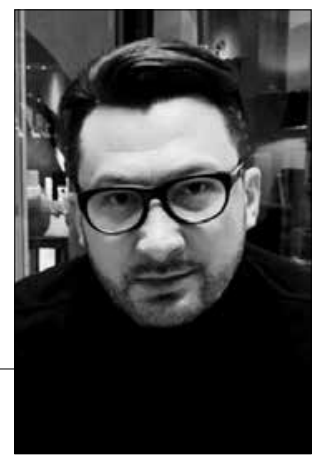

\title{
DISKURSYVIOJI PRAKTIKA KAIP KOMUNIKATYVIOSIOS SĄMONĖS ŽENKLO KONSTRUKTAI
}

\author{
Discursive Practices as Sign Constructs \\ of Communicative Consciousness
}

\begin{abstract}
SUMMARY
The article offers the definition of discursive practice as a sign construct of the cognitive-semiotic, discursive-pragmatic and linguacultural levels, realised in the corresponding discursive situations, within which a semiotic configuration of elements of both one discursive practice and their combination occurs. In a cognitive-semiotic perspective, a discursive space is formed by the symbiosis of discursive practices as signs of a person's communicative consciousness, i.e. a representative of a particular national-cultural community. In this aspect, the discourse is associated with the consciousness, knowledge and perceptions of the language personality, which are formed in the process of socialisation and become the basis of the cultural array, broadcast from generation to generation within a certain ethnic group. Thus, sign constructs of communicative consciousness are formed as concrete semiotic units embodied in discursive practices.
\end{abstract}

\section{SANTRAUKA}

Straipsnyje pateikiamas diskursyviosios praktikos apibrėžimas kaip pažintinio-semiotinio, diskursyviojopragmatinio ir lingvakultūrinio lygmenų konstruktas, realizuojamas atitinkamose diskursyviosiose situacijose, kuriose jivyksta ir vienos diskursyviosios praktikos, ir jos elementu derinio semiotinė konfigūracija. Kognityvinėje-semiotinėje perspektyvoje diskursyviąją erdvę formuoja diskursyviųjų praktikų kaip asmens komunikatyvios sąmonės požymių simbiozè. Šiuo aspektu diskursas susijęs su kalbos vartotojo sąmone, žiniomis ir suvokimu, kurie formuojasi socializacijos procese ir tampa tam tikroje etninëje grupeje iš kartos i kartą perduodamos kultūrinės bazės pagrindu. Taigi komunikatyvios sąmonės ženklų konstruktai - tai diskursyviojoje praktikoje esantys konkretūs semiotiniai vienetai. 


\section{INTRODUCTION}

Modern language / speech reality, identified in various types of discursive / communicative activities and explored in the framework of a variety of methodological approaches, is an inexhaustible source of scientific interest, the development of language theories and the expansion of humanitarian knowledge in general (J. Baker, F. Batsevych, R. Benedict, A. Wierzbicka, I. Sternin et al.). The elucidation of the linguological mechanisms of structuring reality in the minds of speakers of different languages of the world is associated both with the establishment of universals and the identification of specific characteristics actualized by globalisation, sociocultural and national-historical differences.

The interest concerning the national communicative / discursive dimension activates the processes associated with the scientific systematisation of the provisions and explanations in the field of ethnic specificity of communication (Hymes 1972; Krasnykh 2004). Analysing in the research (Korolyov 2018, 2019) the national cooperative communicative behaviour of representatives of Ukrainian, Russian, Lithuanian and American language community, one cannot ignore such a significant phenomenon as the discursive dimension within which there is mono-and intercultural interaction: "The task of building a discursive / communicative dimension becomes the formation of a single picture of the world, which contributes to the unity of the nation" (Pocheptsov 2001: 299).

The focus of cognitive semiotics is the concept of discursive thinking, suggested by A. Luriya. He used the term "discursive" as a synonym for "speech". The scholar understands discursive consciousness as a mechanism that "allows one to delve deeper into the meaning of things, go beyond the limits of direct impression, organise your purposeful behaviour, reveal complex relationships and relationships inaccessible to direct perception, transfer information to another person" (Luriya 1998: 323). In terms of cognitive-discursive semiotics (Alefirenko 2007; Vasko 2019; Korolyov 2018; Sheygal 2000) we propose to consider national communicative behaviour, the basis of which is the concept of "national language personality" (Sedov 2004; Halupo 2016). It is its semiotic centre and subject of discursive practices, a representative of a particular ethnic strength: a carrier of mentality, national character, language, national value dominants, label ritual norms and stereotypes. To establish universal and specific features of the latter can be, in particular, using the formalised complex methodology for the comparable study of stereotypical national discursive practices from the standpoint of cognitive semiotics, psycholinguistics and linguistic discoursology. They determine the methodological basis of the corresponding study, the basic provisions of which are the understanding of language as a sign system and a means of displaying objective reality, language interaction and thinking, the correlation of language and culture and the like. 


\section{DISCOURSE AS COGNITIVE-SEMIOTIC PHENOMENON}

In linguistic works of recent years, discourse is considered as a multidimensional phenomenon (Alefirenko 2007; Arutyunova 1998; Batsevych 2004; Pocheptsov 2001; Brown, Yule 1996) taking into account cognitive (Fairclough 1992), ethnopsychological (Krasnykh 2004), cultural (Lebedko 1999; Wierzbicka 1994), social (Gorelov 2001; Sedov 2004; Darginavičienè 2019), political (Makarov 2003; Sheigal 2000) and other factors.

The widespread use of the term "discourse" does not at all mean that it already has content that could be considered common (Kubryakova 2005: 23). The theory of discourse, as a pragmatised form of the text, originates from the concept of E. Benveniste, where the plan of the narration and the plan of discourse, the language, are distinguished, assigned to the speakers. The scientific legacy of the French scholar defines primarily a conceptual-discursive theory, within which the static plan of the narration and the dynamic plan of discourse are clearly differentiated. The latter is defined as "any statement that determines the presence of communicants: addressee, address of the sender, as well as the addressee's intentions in a certain way influence your interlocutor "(Benveniste 1975: 276-279).

In modern linguistics there is no unity of views regarding the interpretation of the term "discourse". However, in most of the works of scholars devoted to various aspects of discourse (Alefirenko 2007; Dijk van 1989; Krasnykh 2004; Makarov 2003; Sedov 2004), there is a tradition in which "style" refers to a holistic speech composition in the diver- sity of its cognitive-communicative functions. T. van Dijk defines discourse as a communicative event (a complex unity of the language form, meaning and action), recreated by the participants in communication; an event in which not only language is involved in its actual use, but also those mental processes that inevitably accompany the communication process (Dijk van 1989: 121).

There is the following definition of N. Arutyunova represented in the "Linguistic Encyclopaedic Dictionary": "Discourse (from the French. Discours speech) is a coherent text in its totality with extralinguistic - pragmatic, sociocultural, psycholinguistic and other factors; speech is considered as a targeted social action as a component involved in the relationships of people and in the mechanisms of their consciousness (cognitive processes). Discourse is speech "immersed in life" (LES 1990: 136-137).

The definition of discourse proposed by N. Alefirenko is relevant for illuminating the cognitive semiotic perspective of national communicative behaviour: "[...] in cognitive semiology the attention is mainly focused on discursive thinking, if the discourse is understood as a synergistic in its meaning communicative cognitive phenomenon, the ingredients of which, except the text, are various extralinguistic contexts, consitutions, presuppositions, postposition (knowledge of the world, thoughts, value orientations) that are games they play an important role in understanding and hiding information" (Alefirenko 2007: 146).

F. Batsevych distinguishes discourse, speech genre, speech act from other com- 
municative categories, partially interpreting discourse as a type of communicative activity, an interactive phenomenon, a speech flow having various forms of manifestation (oral, written, paralingual). It occurs within a specific communication channel, it is regulated by strategies and tactics of participants; the synthesis of cognitive, linguistic, and extralinguistic (social, mental, psychological, etc.) factors that are determined by a specific circle of life forms that depend on the subject of communication results in the formation of various speech genres (Batsevych 2004: 138).

On the one hand, discourse is a text immersed in life with special grammar, vocabulary, rules of usage and syntax, and on the other hand, it is live communication, communication, cognitivespeech and interactive phenomenon with all the attendant components of communication (Batsevych 2010: 12-13). The discourse, understood as a text immersed in a communication situation, can involve many dimensions. From the perspective of pragmalinguistics, the discourse is an interactive activity of communication participants, the exchange of information, the use of various communication strategies, their verbal and non-verbal embodiment in the practice of communication (Dijk van 1990, 1998).

V. Krasnykh notes that human behaviour is necessarily ethnoculturally marked, because there is also a linguocognitive plan, determining the national specificity of the discursive dimension in the discourse, as well as in communication, in addition to the linguistic proper. One cannot but agree with the scholar that the most important compo- nent of the discourse is cultural (Krasnykh 2004: 244-245).

The categories of communicative linguistics, discourse studies (I. K.) and linguistic pragmatics (discursive / communicative dimension, speech genre, communicative / discursive situation, communicative (speech) act / discursive practice) are interconnected and the parts are interconnected according to the principle of hyper-hyponymic relationships (Batsevych 2005: 91). In our opinion, there is every reason to consider the relationship between the speech genre and the communicative situation hierarchical: speech genres consist of a set of communicative situations, which, in turn, is a complex set of speech acts and / or discursive practices. National communicative behaviour is the formation of language / communicative consciousness and cognitive-semiotic and discursive dimension within certain speech genres that are formed by a set of discursive situations. At the same time, representatives of the discursive space within which national communicative behaviour occurs are discursive practices as semiotic (symbolic) components of communicative consciousness and discursive situations.

In modern science discourse can be understood as different types of actualisation of the text as an abstract, formal, sign construction, considered from the point of view of mental cognitive-semiotic processes in connection with extralinguistic factors; a complex communicative, cognitive-semiotic phenomenon, speech action, taking into account the sociocultural context and characterises the participants in communication, as well as the processes of production and perception of the message. 


\section{SIGN STATUS OF DISCURSIVE PRACTICES IN COMMUNICATIVE CONSCIOUSNESS}

In the theory of communication, the concept of "discursive / communicative dimension" is interpreted quite broadly: 1) the territory within which the interaction takes place; the dimension in which the communicative process takes place (Sharkov 2005: 98): 2) the totality of the spheres of verbal communication in which a particular linguistic personality can realise, in accordance with the language, cognitive and pragmatic rules adopted in a particular society, the necessary needs of his / her being (Prokhorov 1999: 60); 3) a zone of real and potential contacts of each of the participants of communication from the position of the speaker (addressee), within which each of them has his / her own vision of the communicative process, his / her role in it, personal value orientations and ideas about a particular subject of speech (Vorontsova 2009: 13): 4) a heterogeneous entity that functions in culture and society as something single [...] aggregate and the result of areal organic social communications, regional realities and knowledge about them [...]. All of them are represented in the language (Maslova 2017: 22). The emphasis in understanding the discursive / communicative dimension ranges from geographical and social to pragmatic and linguacultural.

Separate national discursive dimensions are similar in structure and content, and therefore it is easier for their subjects to come to an understanding, because they in their communicative behaviour and speech activity rely on the common constants and value dominants of com- municative consciousness. On the other hand, if certain national value orientations are formed by opposition (opposite) constants and dominants in the communicative consciousness of individuals representing different language cultures, then their discursive dimensions are different, because the subjects find themselves in an unfamiliar environment, feeling "like on another planet" and trying to actualise all their knowledge. In this case, as a rule, we are speaking about the intercultural aspect of communicative interaction, the so-called "clash" of different cultures and languages occurs, caused by the mismatch between the constants and value dominants of the communicative consciousness of the interactive. Consequently, we can speak about the "emergence" of one's own and another's "dimension" of the subject's stay, where the transfer of knowledge from one's communicative space to another, as a rule, does not give the expected result, because the value orientations do not coincide" (Kharchenko 2003: 38).

The national discursive / communicative dimension is determined by the socio-historical experience of a certain ethnicity, which accumulates an integrated set of norms, laws, traditions that has developed up to a certain moment and is fixed in specific (non) verbal signs: words, utterances, modern clichés, phraseological units, precedent texts, etc. Corresponding linguacultural units form one or another discursive dimension at a particular stage, at a certain time, along with "communicative behaviour of a 
person, having relatively standardised forms (communicating with (not) familiar, with colleagues, at school and university, in transport, clinic, restaurant and café" (Sternin 2003: 10). There are specific constants, value guidelines and dominants that are embedded in the communicative consciousness of representatives of a certain linguaculture (Dementyev 2013: 63).

From the standpoint of the interaction of language and culture, the national discursive dimension has its own essence and purpose, i.e. it is regulated by certain norms and laws of communication, formed on the basis of constants and value dominants of the communicative consciousness of representatives of a separate linguaculture. Language / communicative consciousness is a formant and regulator of national communicative behaviour, and therefore clearly corresponds to the concept of discursive practice, which Foucault defined as "[...] a set of anonymous historical rules, always defined in time and space, which were established in a certain era and for specific social, economic, geographical or linguistic dimension conditions for the realisation of the function of utterance" (Foucault 1996: 117-118). According to the concept of the language nature of thinking, the scholar reduces the activities of people in their "speech actions", i.e. discursive practices. Actually, the concept of discursive practice can be applied both to a fragment of a discourse of any volume: from a replica in a dialogue with a narrative [Ibid.], and to any type of national communicative behaviour, including cooperative, intermediate and conflict.

To characterise the discursive dimension of national communicative behav- iour in cognitive-semiotic and discursively pragmatic dimensions, it is important to take into account both its place and environment, as well as language, cultural signs, interact, forming the corresponding areas of functioning, i.e. the discursive situations realised by an unlimited spectrum of discursive practices are symbolic constructs language / communicative consciousness. The set of spheres (discursive situations) of discursive practices creates a polydiscursive dimension (Kazydub 2006; Plotnikova 2008) of national communicative behaviour, which can be described as interpersonal, dynamic (verbal / written), open communication based on collaboration / interaction is interactive and mainly occurs in everyday (non-)institutional communicative sphere through a language, paralinguistic code. It is advisable to attract the experimental component of the method of clarifying stereotypical ideas about the discursive dimension of communicative behaviour of respondents belonging to different ethnic cultures, which were formed in their cognitive base as a result of the socio-historical development of a certain ethnic culture and reflect the constants and dominants of communicative consciousness. The obtained results of such psycho- and sociolinguistic experiments make it possible to adequately and transparently perceive, in mono- and intercultural communication, nationally specific language / speech data material, caused not only by the norms of a particular language, but also by traditions, communicative ethnic stereotypes, etc.

In our understanding, discursive practices not only have a symbolic status in the plane of the discursive dimension 
of national communicative behaviour, but also serve as its indicator indicators. Such an interpretation became possible as a result of an experimental study of the national cooperative communicative behaviour of Ukrainian, Russian, Lithuanian and American (see Korolyov 2018). Using the anthropometric method in the form of questionnaires, surveys and linguistic interviews within psycho-sociolinguistic experiments, it was possible to collect and process the actual linguistic / verbal factual data material. It helped to establish and model verbal representatives of national cooperative communicative behaviour, i.e. a repertoire of stereotypical discursive practices of greeting, acquaintance, invitation, request, consent, praise / compliment, gratitude / appreciation, apology, sympathy / compassion / empathy / consolation, wish / desire and good bye as construction signs, reflected in the communicative consciousness of Ukrainian, Russian, Lithuanian and American, performing the functions of regulation, structuring and organisation of communicative interaction.

The range of answers-reactions received from informants, i.e. representatives of Ukrainian, Russian, Lithuanian and American communicative cultures, made it possible to establish types of discursive practices as sign constructs of the communicative consciousness of respondents, including determining their productivity index in the modes of politeness / tolerance, neutrality and familiarity of cooperative communicative behaviour, as well as to construct a frame-scenario model of the latter (Korolyov 2018). The appropriate identification of various types of stereotypical national cooperative discursive practices allows us to qualify them as signs-constructs of communicative consciousness, which are representative of national communicative behaviour and constituting factors for the successful implementation of cooperative macrostrategy.

The experimental results allowed us to conclude that national (cooperative, intermediate, conflicting) discursive practices are constructs of language / communicative consciousness, culture and discourse that, during semiosis, preserve and reproduce stereotypical representations in structurally stable combinations of words as a result symbiosis inherent in the meaning and form of iconic formations.

\section{CONCLUSIONS}

In the cognitive-semiotic perspective, the discursive dimension is formed by the symbiosis of discursive practices as sign constructs of the language / communicative consciousness of a person, i.e. a representative of a particular national-cultural community. In this aspect, the discourse is associated with the speaker's consciousness, knowledge and ideas, which are formed in the process of socialisation and become the basis of that cultural mass, transmitted from generation to generation within a certain ethnic group, forming signs of communicative consciousness as concrete semiotic constructs that are embodied in dis- 
cursive practices. Discursive practice as a sign construct of the cognitive-semiotic, discursive-pragmatic and linguacultural levels is actualised in the corre- sponding discursive situations, within which a semiotic configuration of elements of both one discursive practice and their combination occurs.

\section{References}

Arutyunova Nina D. 1998 - Арутюнова Нина Д. 1998. Язык и мир человека [The language and the world of man]. Москва: Языки русской культуры.

Benedict Ruth. 1934. Patterns of Culture. Boston New York: Houghton, Mifflin and Company.

Brown Gillian, Yule George. 1996. Discourse Analysis. Cambridge: Cambridge University Press.

Darginavičienè Irena. 2019. Multimodality in communication. Logos 98: 146-153.

Dijk Van T. A. 1989 - Дейк ван Тойн А. 1989. Язык. Познание. Коммуникация [Language. Cognition. Communication]. Москва: Прогресс.

Dijk Van T. A. 1990. Discourse \& Society: a new journal for a new research focus, Discourse $\mathcal{E}$ Society. № 1: 5-16.

Dijk van T. A. 1998. Principles of Critical Discourse Analysis, The sociolinguistic Reader. Vol. 2: Gender and Discourse: 367-393.

Fairclough Norman. 1992. Discourse and text: linguistic and intertextual analysis within discourse analysis, Discourse and Society. № 3: 192-217.

Hymes Dell H. 1972. On Communicative Competence, Sociolinguistics. Selected Readings: 269-293.

Lebedko Maria. 1999. Cultural Bumps: Overcoming Misunderstandings in Cross-Cultural Communication. Vladivostok: Far Eastern State University Press.

Vasko Roman. 2019. Reflection of the Ancient Rituals Semiotics in Cultural Etiquette Forms of Politeness. Logos 100: 85-94.

Wierzbicka Anna. 1994. "Culture scripts": A semantic approach to cultural analysis and crosscultural communication, Pragmatic and Language Learning: Monograph Series. Vol. 5: 1-24.

Alefirenko Nikolay F. 2007 - Алефиренко Николай Ф. 2007. Когнитивная семиология: истоки, становление и перспективы развития [Cognitive semiology: origins, formation and development prospects], Известия Южного федерального университета. Филологические науки. № 1-2: 143-152.

Batsevych Florii S. 2004 - Бацевич Флорій C. 2004. Основи комунікативної хінгвістики [Funda-

mentals of Communicative Linguistics]. Київ: "Академія".

Batsevych Florii S. 2005 - Бацевич Флорій С. 2005. Аінгвістична генологія: проблеми і перспективи [Linguistic genealogy: problems and perspectives]. Пьвів: ПАІС.

Batsevych Florii S. 2010 - Бацевич Флорій С. 2010. Нариси з лінгвістичної прагматики [Essays on linguistic pragmatics]. Пьвів: ПАІС.

Benveniste Emile. 1975 - Бенвенист Эмиль. 1975. Общая хингвистика [General Linguistics]. Москва: Прогресс.

Vorontsova T. А. 2009 - Воронцова Т. А. 2009. Коммуникативное пространство в дингвопрагматической парадигме [Communicative dimension in a linguopragmatic paradigm], Вестник удмуртского университета. Серия: История и филология. Вып. 1: 11-17.

Gorelov Ilia N., Sedov Konstantin F. 2001 - Гopeлов Илья Н., Седов Константин Ф. 2001. Основы психолингвистики [Fundamentals of Psycholinguistics]. Москва: Лабиринт.

Dementyev Vadim V. - Дементьев Вадим В. 2013. Коммуникативные иенности русской культуры: категория персональности в лексике и прагматике [Communicative values of Russian culture: category of personality in vocabulary and pragmatics]. Москва: Глобал Ком.

Korolyov Igor R. 2018 - Корольов Ігор P. 2018. Національна кооперативна комунікативна поведінка: від когніції до дискурсу [National coоperative communicative behaviour: from cognition to discourse]. Київ: ВПЦ “Київський університет".

Korolyov I. 2019. Cognitive and communicative category of cooperativity: ontological and gnoseological status, Logos. 98: 83-93.

Kazydub Nadezhda N. 2006 - Казыдуб Надежда Н. 2006. Дискурсивное пространство как фрагмент языковой картины мира (теоретическая модель) [Discursive dimension as a fragment of the linguistic picture of the world (theoretical model)]. Иркутск: ИГАУ. 
Krasnykh Viktoriya V. 2004 - Красных Виктория В. 2004. Анализ дискурса в свете концепции фрейм-структур сознания [Discourse analysis in the light of the concept of frame structures of consciousness], Культурные слои во фразеологизмах и в дискурсивных практиках / отв. ред. В. Н. Телия. Москва: 243-245.

Kubryakova Elena S. 2005 - Кубрякова Елена C. 2005. О термине дискурс и стоящей за ним структуре знания [On the term discourse and the structure of knowledge behind it], Языюк. Аичность. Текст. Москва: Языки славянской культуры: 23-33.

Luriya Aleksandr R. 1998 - Лурия Александр Р. 1998. Язык и сознание. Серия: Психологические этюды [Language and consciousness. Series: Psychological Studies]. Под ред. Е. Д. Хомской. Ростов-на-Дону: Феникс.

LES. 1990 - ЛЭС - Лингвистический энизиклопедический словарь [Linguistic Encyclopaedic Dictionary] 1990. Гл. ред. Ярцева В. Н. Москва: Советская энциклопедия.

Makarov Mikhail L. 2003 - Макаров Михаил $\Lambda$. 2003. Основы теории дискурса [Fundamentals of Discourse Theory]. Москва: Гнозис.

Maslova Valentina A. 2017 - Маслова Валентина А. 2017. Коммуникативное пространство как важнейшая категория современной лингвистики и дингвокультурологии [Communicative dimension as the most important category of modern linguistics and linguaculturology], Вестник РУДН. Серия: Теория языка. Семиотика. Семантика. Т.8. №1: 17-23.

Plotnikova S. N. 2008 - Плотникова С. Н. 2008. Языковое, дискурсивное и коммуникативное пространство [Linguistic, discursive and communicative dimension], Вестник ИГАУ. Сер. Филология. Язык. Культура. Коммуникация. Вып.1: 131-136.

Pocheptsov Georgiy G. 2001 - Почепцов Георгий Г. 2001. Теория коммуникации [Communication theory]. Москва: Рефл-бук; Киев: Ваклер.
Prokhorov Yuriy E. 1999 - Прохоров Юрий Е. 1999. Коммуникативное пространство языковой дичности в национально-культурном аспекте [Communicative dimension of linguistic personality in the national-cultural aspect], Язык, сознание, коммуникация: сборник статей. Вып. 8: 52-63.

Sedov Konstantin F. 2004 - Седов Константин Ф. 2004. Дискурс и хичность: эволюция коммуникативной компетенциии [Discourse and personality: the evolution of communicative competence]. Москва: Лабиринт.

Sternin Iosif A., Larina Tatiana V., Sternina Marina А. 2003 - Стернин Иосиф А., Ларина Татьяна В., Стернина Марина А. 2003. Очерк английского коммуникативного поведения [Essay in English Communication Behavior]. Воронеж: Изд-во "Истоки".

Foucault Paul-Michel 1996 - Фуко Поль-Мишель. 1996. Археология знания [Archeology of knowledge] / пер. с фр., общ. ред. Бр. Аевченко. Киев: Ника-Центр.

Khalupo Olga I. 2016 - Халупо Ольга И. 2016. Аингвокультурные аспекты взаимодействия субъектов нациионалных коммуникативных пространсть [Linguacultural aspects of the interaction of subjects of national communication dimensions]: диссертация доктора филол. наук. Челябинск.

Kharchenko Elena V. 2003 - Харченко Елена В. 2003. Модели речевого поведения в профессиональном общении [Speech Behaviour Models in Professional Communication]. Челябинск: Изд-во ЮУрГУ.

Sharkov Feliks I. 2005 - Шарков Феликс И. 2005. Теория коммуникации (базовый курс) [Communication Theory (basic course)]. Москва: Экзамен.

Sheygal Elena I. 2000 - Шейгал Елена И. 2000. Семиотика политического дискурса [Semiotics of Political Discourse]. Москва; Водгоград: Перемена. 